\title{
Can lymphocyte to monocyte ratio be used as a predictor of atherosclerotic carotid plaques in elderly adults?
}

\section{Lenfosit/monosit oranı yaşlı erişkinlerde aterosklerotik karotis plaklarınının bir göstergesi olarak kullanılabilir mi?}

\section{Asli Bolayir, Eretugrull Bolayir}

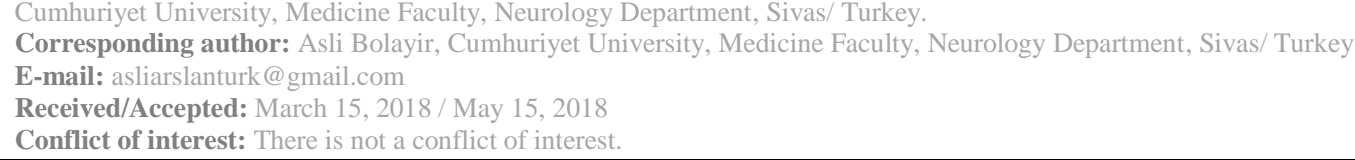

\section{SUMMARY}

Objective: The aim of our study was to determine retrospectively the association of LMR with carotid stenosis, evaluated by carotid artery doppler ultrasonography.

Method: Our study included 102 patients, aged $\geq 65$ years, hospitalized in our clinic from January 2011 to December 2017. Blood samples were taken from all of the patients to determine the levels of white blood cell subtypes. LMR was calculated as the ratio of lymphocyte count to monocyte count. Patients also underwent carotid artery doppler ultrasonography to define the presence of carotid stenosis.

Results: After dividing the patient group into two subgroups according to carotid stenosis, the patients with severe stenosis (carotid stenosis> 50\% $)(n=42)$ had lower lymphocyte count and LMR value but higher monocyte count. Then the patient group with carotid stenosis $>50 \%$ were divided into two subgroups again. While a statistically significant difference was found between the LMR values of these 3 groups, this difference was in favor of the first group(carotis stenosis $<50 \%$ ). The optimum cut-off LMR values was determined as 2.49 with a sensitivity of $72.6 \%$ and a specificity of $80.7 \%$.

Conclusions: Lower levels of LMR can be used as a strong predictor of the presence of severe carotid stenosis in elderly adults.

Keywords: white blood cell subtypes, lymphocyte/ monocyte ratio, inflammation, atherosclerosis, carotid artery stenosis

ÖZET

Amaç: Bu çalışmadaki amacımız geriye dönük olarak LMO’nun karotis arter doppler ultrasonografi ile saptanmış karotis stenozu ile ilişkisini saptamaktır.

Yöntem: Çalışmamız 65 yaş ve üzerinde, Ocak 2011- Aralık 2017 tarihleri arasında kliniğimizde takip edilen 102 hastay1 içermektedir. Tüm hastalardan beyaz küre alt tiplerinin ölçümü için kan örneği alındı. LMO değeri lenfosit sayısının monosit sayısına oranı olarak hesaplandi. Hastalara ayrıca karotis stenozunu saptamak için karotis arter doppler ultrasonografisi de uyguland1.

Bulgular: Hasta grubu karotis stenozu ciddiyetine göre iki alt gruba ayrıldıktan sonra, ciddi darlığı olan hastaların(karotis stenozu> \%50)(n=42) daha düşük lenfosit sayısı ve LMO değerine ancak daha yüksek monosit sayısına sahip olduğu saptandı. Daha sonra karotis stenozu \%50’nin üzerinde olan hastalar tekrar iki alt gruba ayrıldı. Her üç grup arasında LMO değeri açısından istatistiksel olarak anlamlı fark saptanırken; bu fark birinci grup lehineydi.(karotis stenozu <\%50). LMO değeri için en iyi kesim noktası \%72.6 duyarlılık ve \%80.7 seçicilikle 2.49 olarak saptandı.

Sonuç: Düşük LMO seviyeleri yaşlı erişkinlerde ciddi karotis stenozunun varlığı için güçlü bir gösterge olarak kullanılabilir.

Anahtarsözcükler: Beyaz küre alt tipleri, lenfosit/monosit oranı, inflamasyon, ateroskleroz, karotis arter stenozu. 


\section{INTRODUCTION}

Cerebrovascular disease, which is the most common neurological cause of emergency admission, has very high mortality and morbidity rates especially in the elderly population. Acute ischemic stroke(AIS) accounts for $80 \%$ to $85 \%$ of all cerebrovascular diseases ${ }^{1}$. Nowadays, effective treatment of AIS is limited; therefore it is very important to control risk factors in the best possible way. This is only feasible with a good understanding of the underlying pathogenic mechanisms in AIS.

Among the etiologic factors of AIS, large artery atherosclerosis has a great importance ${ }^{2}$. It has shown with recently studies that inflammation has a significant role in the development and progression ofatherosclerosis ${ }^{3,4}$. In fact, inflammatory cells contributeto all stages of atherosclerotic lesion, from initiation to disruption, leading in turn to AIS, as a consequence of atherosclerotic plaque instability or rupture ${ }^{5}$. Some inflammatorymarkers like CRP and fibrinogen, areknown as parameters associated with atherosclerosis ${ }^{4}$. Additionally, the last evidences have revelaed that some of theWBC subtypes may be used to show inflammation ${ }^{6,7}$.

It has been showed that the lymphocyte count could decrease in inflammatory state ${ }^{8}$. The decline of lymphocytes is secondary to lymphocyte apoptosis and redistribution of lymphocytes to lymphatic organs that is induced by inflammation. It has also been revealed that the decrease of lymphocyte count may be related with poor prognosis and longterm functional recovery after AIS ${ }^{9}$.

Microglial cells are considered to be major cells that contribute to inflammation ${ }^{10}$. Macrophages and monocytes, which are the precursor cells of macrophages, have also been shown to play an important role in all stages of atherosclerosis, from fatty streak formation to plaque rupture, and even AIS development ${ }^{11}$. Increased amounts of circulating macrophages and monocytes, the source of foam cells, are considered a predictor of new plaque formation ${ }^{12}$.

Recently, the lymphocyte/ monocyte ratio(LMR), a rapid and easy method for assessing the inflammation and calculated by dividing the lymphocyte count to monocyte count, has been accepted as a novel marker for cardiovascular diseases and atherosclerosis development ${ }^{9,13}$. Recent studies have found low LMR levels in patients with AIS, which is inversely correlated with neurological disability after AIS. However, the association of LMR with carotid stenosis is unknown. So, the aim of our study was to determine retrospectively the relationship between LMR and carotid stenosis, evaluated by carotid artery doppler ultrasonography.

\section{MATERIAL AND METHODS}

\section{Study Population:}

Our retrospective study included 102 patients, aged $>65$ years and complained of dizziness. These patients, who had computerized brain tomography or cranial magnetic resonance imaging for exclusion of cerebrovascular disease, were admitted to the Cumhuriyet University Neurology Department, from January 2011 to December 2017. Patients with no diagnosis ofcentral vertigo and bilateral carotid artery doppler ultrasonography were included in our study. Our exclusion criteria were prensence of systematic acute/chronic inflammatory/autoimmune diseases, history of infection within 2 weeks before admission, chronic connective tissue diseases, hematological disorders, cancer, severe liver, kidney or heart failure, acute coronary syndrome within the past three months, prior acute myocardial infarction, a history of major surgery or trauma, chronic alcohol abuse and using immunosuppressants, anti inflammatories or steroids.

The baseline demographic and clinical information of the patients(age, gender, the presence of risk factors such as hypertension(defined as the systolic blood pressure above $140 \mathrm{mmHg}$ and/or the diastolic blood pressure above $90 \mathrm{mmHg}$, or the use of antihypertensive therapy), diabetes mellitus (defined as the fasting blood glucose level above $126 \mathrm{mg} / \mathrm{dl}$ and/or the use of antidiabetic therapy), hyperlipidemia(defined as the fasting total cholesterol value above $200 \mathrm{mg} / \mathrm{dl}$ and/or the triglyceride value above $150 \mathrm{mg} / \mathrm{dl}$ (National Cholesterol Education Program Adult Treatment Panel III guideline)) and tobacco(current smoker or having quit in the last 6 months) and statin use)was obtained from patient records in the hospital system. Some of these patients were interviewed on the phone to provide the missing information of the study.

Approval by the ethics committee of Cumhuriyet University was obtained for the study.

\section{Collection of Samples and Laboratory Analysis:}

The blood samples were taken from antecubital vein to dry tubes and to tubes containing ethylenediaminetetraacetic acid (EDTA). While dry tubes were used for the biochemical analysis, 
EDTA tubes were used for the hematological test. The complete blood counts were analyzed with the Diagon kit on the Mindray BC-6800 device and the lymphocyte and monocyte counts of the patients were obtained from this data. The LMR values were determined by dividing the number of lymphocytes by the number of monocytes. Biochemical analyses(glucose, plasma creatinine, uric acid, C-reactive protein (CRP), total cholesterol, low-density lipoprotein, low-density lipoprotein, triglyceride levels) were performed with a Beckman Coulter AU5800 device (Beckman Coulter Inc, Hialeah, Florida) using kits produced by the same company via a fully automatic nephelometric method.

Before the carotid US examination, patients rested in the supine position for 15 minutes. Bilateral common carotid arteries (CCA), carotid bifurcations, internal carotid and external carotid arteries inlongitudinal and transverse planes were scanned using a3.5e10 MHz linear multi-frequency transducer (Toschiba -2900 or G device 320). Intima media thickness (IMT) was estimatedin longitudinal plane, in a region free of atherosclerotic plaques of the common carotid artery far wall, at $0.5,1$, and $1.5 \mathrm{~cm}$ from the carotid bifurcation, taking for analysis the average of the three measurements. The presence of significant atherosclerotic stenosis of carotid arterywas identified in transverse plan and defined as a focal structure that $\geq 50 \%$ of the surrounding IMT value.

\section{Statistical analysis:}

The data obtained from our study were loaded on the SPSS (Ver: 22.0) program and evaluated. Continuous data are stated as mean $\pm \mathrm{SD}$, while categorical data as frequencies and percentages. When proportions were compared by chi-square test with Yates' correction for continuity or Fisher's exact test, as appropriate; comparison of continuous variables was performed by Student's ttest. Data are reported as mean \pm standard deviation when a Gaussian distribution of values was observed, and as median and interquartile range in presence of a non Gaussian distribution of values. The Kruskal-Wallis $\mathrm{H}$ test was used to compare the values of the three independent groups. Receiver operating characteristic curves (ROC) analysis were established to determine the optimum cut-off values of LMR and CRP for predicting the carotid artery stenosis. A p value $<0.05$ was considered statistically significant.

\section{RESULTS}

The baseline demographic/ clinical characteristics and laboratory findings of patientsincluded in our study are summarized in Table 1.The mean age was 67.8 years; 53 patients $(52 \%)$ were women; 82 (80\%) hypertensives, 53(52\%) hyperlipidemics, 47 (46\%) diabetics, 41 (40\%) tobacco and 22(22\%) statin user. Then the patients were divided into two subgroups according to the carotid artery doppler ultrasonography results. Patients with bilateral carotid artery stenosis were grouped according to the high percentage of stenosis. While patients in the first group had no significant stenosis (no carotid stenosis or a stenosis below 50\%) $(\mathrm{n}=60)$, patients in the second group had a stenosis $\geq$ $50(n=42)$. These two groups were compared in terms of baseline demographic / clinical characteristics and laboratory data (Table 2). There was no difference in age, gender, statin and tobacco use between the two groups, while the frequency of hyperlipidemia, hypertension and diabetes mellitus presence and LDL values were found higher in the second group $(\mathrm{p}<0.05)($ Table 2$)$. When the lymphocyte and monocyte counts and LMR and CRP values were examined in these groups, the lymphocyte count and LMR value were higher in the first group but the monocyte count and CRP value were higher in the second group (Table 2). Subsequently, the patient group with carotid stenosis $>50 \%$ were divided into two subgroups again. The patients in the first group had a stenosis between $50 \%$ and $70 \%(\mathrm{n}=30)$, whereas patients in the second group had a stenosis $\geq 70 \%(n=12)$. Then these 3 groups(carotis stenosis $<50 \%$ (first group), carotis stenosis $50 \%-70 \%$ (second group), carotis stenosis $\geq 70 \%$ (third group) were compared in terms of lymphocyte and monocyte counts and LMR and CRP values (Table 3). A statistically significant difference was found between the LMR and CRP values of these 3 groups. This difference was in favor of the first group for LMR value; group 3 for CRP value. 
Table 1. The baseline demographic/ clinical characteristics and laboratory findings of the patients.

\begin{tabular}{|c|c|}
\hline & Patient group $(n=102)$ \\
\hline Female, $\mathbf{n}(\%)$ & $53(52 \%)$ \\
\hline HT Presence, n(\%) & $82(80 \%)$ \\
\hline Hyperlipidemia Presence, n(\%) & $53(52 \%)$ \\
\hline DM Presence, n(\%) & $47(46 \%)$ \\
\hline Tobacco use, n(\%) & $41(40 \%)$ \\
\hline Statin use, $\mathbf{n}(\%)$ & $22(22 \%)$ \\
\hline Age $(\operatorname{mean} \pm$ SD $)$ & $67.8 \pm 7.92$ \\
\hline HDL (mg/dL) (median)(IR) & $46(30-76)$ \\
\hline LDL $(\mathbf{m g} / \mathrm{dL})(\operatorname{mean} \pm \mathrm{SD})$ & $82.2 \pm 39.4$ \\
\hline TotalChol $(\mathrm{mg} / \mathrm{dL})($ mean \pm SD $)$ & $184.9 \pm 39.4$ \\
\hline Creatine (mg/dL) (median)(IR) & $0.8(0.5-1.4)$ \\
\hline Glucose $(\mathrm{mg} / \mathrm{dL})($ mean \pm SD $)$ & $142.8 \pm 74.8$ \\
\hline CRP (mg/dl) (median)(IR) & $1.6(0.5-1.5)$ \\
\hline Hb $(g / d L)($ mean \pm SD $)$ & $14.2 \pm 1.5$ \\
\hline WBC $\left(10^{9} / \mathrm{ml}\right)($ median $)(I R)$ & $8.2(4.8-11.4)$ \\
\hline Monocyte $\left(10^{9} / \mathrm{ml}\right)($ mean \pm SD $)$ & $581.39 \pm 93.21$ \\
\hline Lymphocy te $\left(10^{9} / \mathrm{ml}\right)($ mean \pm SD $)$ & $1397.25 \pm 520.08$ \\
\hline Neutrophil $\left(10^{9} / \mathrm{ml}\right)($ mean \pm SD $)$ & $4837.16 \pm 1264.81$ \\
\hline $\operatorname{LMR}(\operatorname{mean} \pm$ SD $)$ & $2.44 \pm 1.19$ \\
\hline
\end{tabular}

All values are presented mean \pm standard deviation(SD), median value (IR) or number(\%). Abbreviations: HT: hypertension; DM: diabetes mellitus; HDL: high density lipoprotein; LDL: low density lipoprotein; TotalCho: total cholestrol; ; CRP: C-Reactive Protein; ; Hb: Hemoglobin; WBC: white blood cell; LMR: Lymphocyte to Monocyte Ratio. 
Table 2. The comprassion of the baseline demographic/ clinical characteristics and laboratory findings of first and second groups.

\begin{tabular}{|c|c|c|c|c|}
\hline & $\begin{array}{l}\text { First } \\
\text { Group }(n=60)\end{array}$ & $\begin{array}{l}\text { Second } \\
\operatorname{Group}(n=42)\end{array}$ & $\mathbf{X}^{2}$ & $\mathbf{p}$ \\
\hline $\begin{array}{l}\text { Female, } \\
\text { n(\%) }\end{array}$ & $31(52 \%)$ & $22(55 \%)$ & 0.01 & $\begin{array}{r}0.9 \\
2\end{array}$ \\
\hline HT Presence, $n(\%)$ & $45(75 \%)$ & $37(88 \%)$ & 3.52 & $\begin{array}{r}0.0 \\
3\end{array}$ \\
\hline Hyperlipidemia Presence, $n(\%)$ & $22(37 \%)$ & $30(71 \%)$ & 4.51 & $\begin{array}{r}<0 \\
01\end{array}$ \\
\hline DM Presence, $n(\%)$ & $30(50 \%)$ & $27(64 \%)$ & 2.76 & $\begin{array}{r}0.0 \\
2\end{array}$ \\
\hline Tobacco use, n(\%) & $24(40 \%)$ & $17(40 \%)$ & 0.03 & $\begin{array}{r}0.9 \\
5\end{array}$ \\
\hline Statin use, n(\%) & $14(23 \%)$ & $8(19 \%)$ & 0.12 & $\begin{array}{r}0.1 \\
2\end{array}$ \\
\hline Age $(\operatorname{mean} \pm$ SD $)$ & $67.9 \pm 7.42$ & $67.7 \pm 6.22$ & & $\begin{array}{r}0.2 \\
2\end{array}$ \\
\hline HDL $(\mathrm{mg} / \mathrm{dL})($ median$)(\mathrm{IR})$ & $47(33-76)$ & $45(30-72)$ & & $\begin{array}{r}0.3 \\
5\end{array}$ \\
\hline$L D L(m g / d L)($ mean $\pm S D)$ & $77.2 \pm 32.4$ & $95.7 \pm 23.4$ & & $\begin{array}{r}0.0 \\
2\end{array}$ \\
\hline TotalChol $(\mathrm{mg} / \mathrm{dL})(\operatorname{mean} \pm$ SD $)$ & $182.7 \pm 32.4$ & $188.6 \pm 26.5$ & & $\begin{array}{r}0.0 \\
8\end{array}$ \\
\hline $\begin{array}{l}\text { Creatine }(\mathrm{mg} / \mathrm{dL}) \\
(\text { median })(\mathrm{IR})\end{array}$ & $0.8(0.5-1.4)$ & $0.8(0.5-1.3)$ & & $\begin{array}{r}0.3 \\
4\end{array}$ \\
\hline Glucose $(\mathrm{mg} / \mathrm{dL})(\operatorname{mean} \pm$ SD $)$ & $141.9 \pm 72.3$ & $145.8 \pm 71.8$ & & $\begin{array}{r}0.2 \\
4\end{array}$ \\
\hline Hb $(g / d L)($ mean \pm SD $)$ & $14.3 \pm 1.3$ & $14.1 \pm 1.4$ & & $\begin{array}{r}0.1 \\
9\end{array}$ \\
\hline WBC $\left(10^{9} / \mathrm{ml}\right)($ median $)($ IR $)$ & $8.1(4.8-11.1)$ & $8.3(4.9-11.4)$ & & $\begin{array}{r}0.3 \\
1\end{array}$ \\
\hline $\begin{array}{l}\text { Neutrophil }\left(10^{9} / \mathrm{ml}\right) \\
(\text { mean } \pm \text { SD })\end{array}$ & $\begin{array}{l}4842.16 \pm 1119 \\
.71\end{array}$ & $\begin{array}{l}4825.16 \pm 1261 \\
81\end{array}$ & & $\begin{array}{r}0.1 \\
1\end{array}$ \\
\hline $\operatorname{Monocyte}\left(10^{9} / \mathrm{ml}\right)(\operatorname{mean} \pm S D)$ & $555.39 \pm 93.21$ & $622.42 \pm 35.00$ & & $\begin{array}{r}0.0 \\
4\end{array}$ \\
\hline Lymphocyte $\left(10^{9} / \mathrm{ml}\right)($ mean $\pm S D)$ & $\begin{array}{l}1467.66 \pm 478 \\
08\end{array}$ & $\begin{array}{l}1291.21 \pm 510 \\
09\end{array}$ & & $\begin{array}{r}0.0 \\
1\end{array}$ \\
\hline$C R P(m g / d l)($ mean $\pm S D)$ & $1.21 \pm 0.52$ & $2.22 \pm 0.63$ & & $\begin{array}{r}<0 \\
01\end{array}$ \\
\hline $\operatorname{LMR}(\operatorname{mean} \pm S D)$ & $2.65 \pm 1.12$ & $2.12 \pm 0.89$ & & $\begin{array}{r}0.0 \\
2\end{array}$ \\
\hline
\end{tabular}

All values are presented $\overline{\text { mean } \pm \text { standard deviation(SD)}}$, median value (IR) or $\overline{\text { number(\%) }}$. Abbreviations: $\overline{\mathrm{CRP}: \mathrm{C}}$ Reactive Protein; HT: hypertension; DM: diabetes mellitus; HDL: high density lipoprotein; LDL: low density lipoprotein; LMR: Lymphocyte to Monocyte Ratio; TotalCho: total cholestrol; Hb: Hemoglobin; WBC: white blood cell. 
Table 3. The comprassion of the monocyte, lymphocyte counts and CRP and LMR values of the first, second and third groups.

\begin{tabular}{|c|c|c|c|c|}
\hline & $\begin{array}{l}\text { First } \\
\text { Group }(n=60)\end{array}$ & $\begin{array}{l}\text { Second } \\
\operatorname{Group}(n=30)\end{array}$ & $\begin{array}{l}\text { Third } \\
\text { Group }(n=12)\end{array}$ & $\mathbf{p}$ \\
\hline $\begin{array}{l}\text { Monocyte }\left(10^{9} / \mathrm{ml}\right) \\
(\operatorname{mean} \pm \text { SD })\end{array}$ & $555.39 \pm 93.21$ & $583.34 \pm 35.12$ & $625.12 \pm 34.25$ & 0.98 \\
\hline $\begin{array}{l}\text { Lymphocyte }\left(10^{9} / \mathrm{ml}\right) \\
(\operatorname{mean} \pm \text { SD })\end{array}$ & $\begin{array}{l}1467.66 \pm 4780 . \\
08\end{array}$ & $1292.05 \pm 410.01$ & $1289.12 \pm 405.02$ & 0.12 \\
\hline $\begin{array}{l}C R P(m g / d l) \\
(m e a n \pm S D)\end{array}$ & $1.21 \pm 0.52$ & $2.09 \pm 0.64$ & $2.55 \pm 0.52$ & 0.01 \\
\hline $\operatorname{LMR}($ mean $\pm S D)$ & $2.65 \pm 1.12$ & $2.17 \pm 0.84$ & $2.00 \pm 0.95$ & $<0.01$ \\
\hline
\end{tabular}

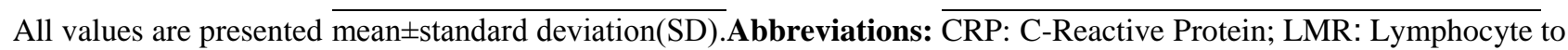
Monocyte Ratio.

In addition, receiver operating characteristic curves (ROC) analysis were established to determine the optimum cut-off LMR and CRP values for predicting the severe carotid artery stenosis in older patients. While the area under the curve (AUC) value of LMR was 0.72 (95\% confidence interval
(CI): $0.66-0.79)$ ), the AUC value of CRP was 0.69(95\% CI:0.63-0.77). The cut-off LMR value was observed as 2.49 with a sensitivity of $72.6 \%$ and a specificity of $80.7 \%$ and the cut-off CRP value was showed as 1.5 with a sensitivity of $73.7 \%$ and a specificity of $79.2 \%$ (Fig. 1).

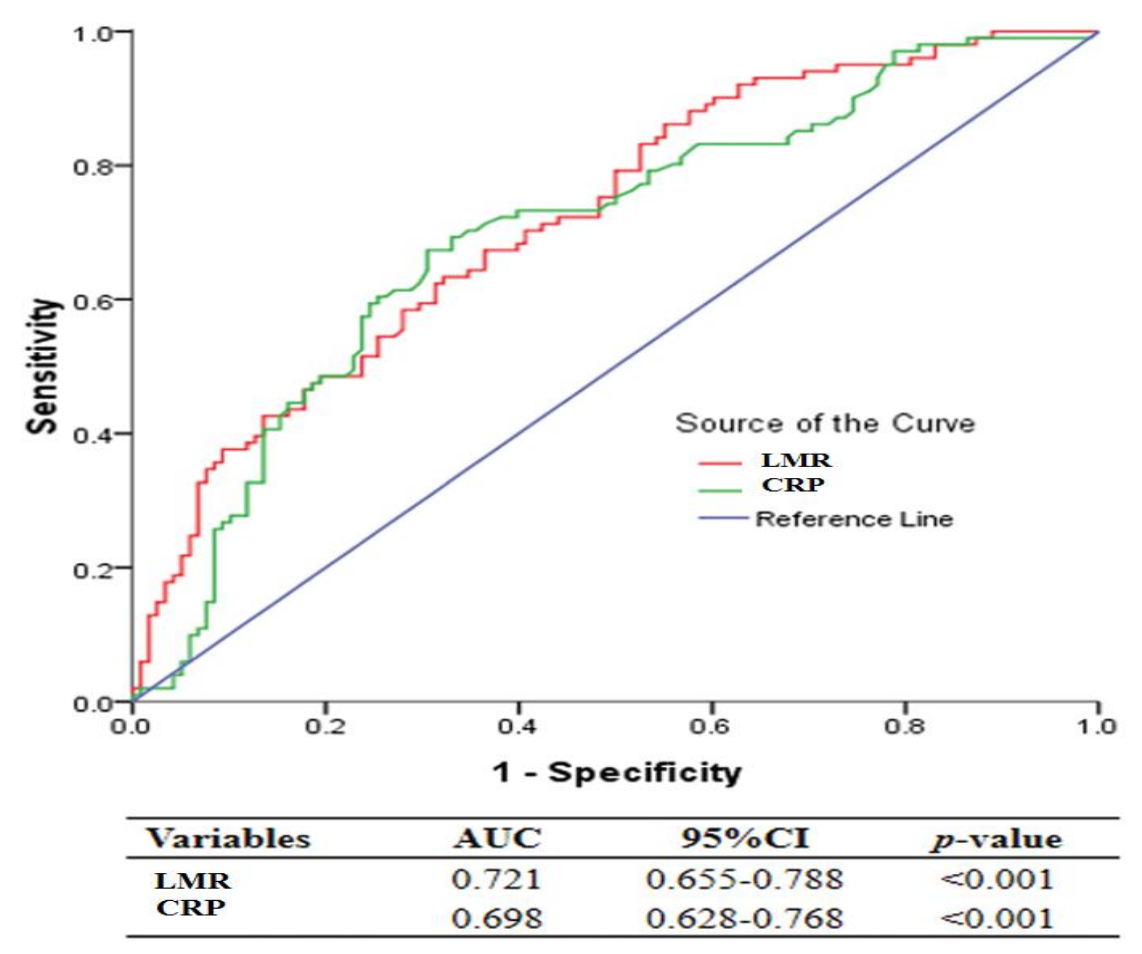

Figure 1. 


\section{DISCUSSION}

In this study we have revealed the potential role of the LMR values of older adults in predicting the presence of carotid atherosclerotic stenosis. This study have showed that lower LMR levels correlate with carotis stenosis severity. Therefore, LMR levels may be accepted as a new marker of carotis atherosclerosis in healthy adultsaged $>65$ years. To our best knowledge this is the first study about this issue.

The carotid atherosclerosis is a well known risk factor for acute ischemic stroke development ${ }^{1,2}$. The contribution of lymphopenia in turn to atherosclerotic plaque has been proved by recent studies ${ }^{14}$. Lymphocytes have a controversial role in the inflammation after AIS. Some rodent studies have recently indicated that increased lymphocyte count was associated with elevated antiinflammatory cytokine, interleukin (IL)-10, and suppressed inflammatory cytokines, like IL-6 and tumor necrosis factor (TNF)- $\alpha$, stimulating neuroprotective effect ${ }^{15}$. This possible mechanism linking lymphopenia to development carotid stenosis may be related to the dysfunction of autonomic nervous system ${ }^{16}$. It was showed that lymphocytes have cholinergic receptors and parasympathetic nervous system stimulates the number and function of lymphocytes. So a supression of parasympathetic nervous system results in decrease of lymphocyte count and this imbalance may be involved in development of atherosclerosis. The increase in sympathetic system is directly proportional to oxygen consumption and proinflammatory cytokine production like IL- 6 and TNF- $\alpha^{17}$. These cytokines contribue to the development of atherosclerosis via stimulating smooth muscle and interstitial cell proliferation. Additionally, the lymphocyte count changes has been revelaed to be related to both cardiovascular diseases and other neurological diseases ${ }^{18}$.

The role of macrophages and monocytes in progression of atherosclerosis is well known ${ }^{9-12}$. After endothelial dysfunction, the first step in atherosclerosis development, monocytes attach and firstly loosely then tightly adhere to the endotelium. After migratation to subendotelium, they mature into macrophages, which are the precursors of foam cells. Foam cells turn into fatty streaks secrete proinflammatory cytokines such as matrix metalloproteinases, tissue factors and growth factors, that stimulate the local inflammatory response around the atherosclerotic lesion $^{19}$. As can be seen, macrophages and monocytes are essential for all stages of carotid atherosclerosis from fatty streak formation to significant stenosis. So it could be supposed that elevated monocytes counts is an indicator of development of new atherosclerotic plaques ${ }^{12}$.

Our study also showed in accordance with these informations that the patients with significant carotid artery stenosis had lower lymphocyte count, higher monocyte count, and therefore lower LMR value. Additionally, in the subgroup analyzes there was no significant difference between lymphocyte and monocyte counts among the three groups according to the carotid stenosis severity, but there was a statistically significant inverse relationship between LMR value and carotis stenosis. Therefore, based on our results, it can be said that LMR value is a more valuable indicator than lymphocyte and monocyte counts alone in revealing carotid stenosis in elderly adults. In addition, LMR values below 2.49 had high sensitivity and specificity to predict the severe carotid stenosis. Moreover, the AUC of ROC curve of LMR (0.72) was almost as large as the AUC of ROC curve(0.69) of CRP, known as a valuable inflammation marker ${ }^{3-5}$.

Unfortunally, there is only a few information about the possible underlying mechanisms between low LMR levels and thecarotis artery stenosis in older adults. But as mentioned before, it is known that lymphocytes acts in the anti-inflammatory direction while monocytes act in the proinflammatory direction during the development of atherosclerosis. Moreover, recent studies have suggested that inflammatory processes contribute to progression of atherosclerotic stenosis ${ }^{3-5}$.

Our study has some limitations. This is a singlecenter study and the number of patients is relatively small. So that the LMR values cannot be extrapolated to the general population. Additionally, it was an observational retrospective study, so that a causal relationship between LMR and atherosclerotic carotid stenosis cannot be warranted. It was also assumed that the patients in our study had normal coronary arteries without performing coronary angiography. Besides, the other inflammatory markers like TNF- $\alpha$, IL- 1 , and IL-6 were not measured.

\section{CONCLUSION}

Finally, lower LMR values in older adults may be associated with carotis artery stenosis and there was a statistically significant inverse relationship between the decline of LMR values and carotis stenosis severity. It is significant, because carotid artery stenosis has a avoidable role in AIS 
development and the LMR value, which can be easily obtained from the whole blood parametres, measured at almost every health instution, does not require any additional expense. More detailed and extensive multicenter prospective studies areneeded to assess our results.

\section{REFERENCES}

1. Balkan S. editör. 3 rd ed.Serebrovasküler hastalıklar. vols 46-61. 3 rd ed. Ankara; 2002.p236-255.

2. Adams HP Jr, Bendixen BH, Kappelle LJ, Biller J,Love BB, Gordon DL, et al. Classification of subtype of acute ischemic stroke. Definitions for use in a multicenter clinical trial. TOAST. Trial of Org 10172 in Acute Stroke Treatment. Stroke 1993;24:3541.

3. Pagram H, Bivard A, Lincz LF, Levi C. Peripheral immune cell counts and advanced imaging as biomarkers of stroke outcome. Cerebrovasc Dis Extra, 2016; 6: 120-28

4. Ross R. Atherosclerosis -an inflmamatory disease. N engl J Med 1999;340:115-26.

5. Tuttolomondo A,Di Raimondo D, Pecoraro R,Serio A, Aguanno G, Pinto A,et al. Immuneinflmammatory markers and arterial stiffness indexes in subjects with acute ischemic stroke. Atherosclerosis 2012;213(1):311-318

6. Kim J, Song TJ, Park JH, Lee HS. Different prognostic value of white blood cell subtypes in patients with acute cerebral infarction. Atherosclerosis, 2012; 222: 464-67

7. Bolayir A, Cigdem B, Gokce SF, Bolayir HA, Kayim Yildiz O,Bolayir E,et al. The Effect of Eosinopenia on Mortality in Patients with Intracerebral Hemorrhage. Journal of Stroke and Cerebrovascular Disease 2017;10(26):2248- 2255.

8. Rodrigues SF, Granger DN. Leukocytemediated tissue injury in ischemic stroke. Curr Med Chem, 2014; 21: 2130-2137

9. Ren H, Liu X, Wang L,Gao Y. Lymphocyteto-monocyte ratio: a novel predictor of the prognosis of acute ischemic stroke. Journal of Stroke And Cerebrovascular Diseases 2017; 26(11): 2595-2602

10. Liberale L, Montecucco F, Bonaventura A, Casetta I,Seraceni S, Trentini A, et al. Monocyte count at onset predicts post-stroke outcomes during a 90-day follow up. Eur J Clin Invest 2017; 47(10): 702-10.
11. Bolayir A,Gokce SF, Cigdem B, Bolayir HA, Kayim Yildiz O,Bolayir E,et al. Monocytes/high-density lipoprotein ratio predicts the mortality in ischemic stroke. NeurologiaiNeurochirurgiaPolska

2017.Article in Press

12. Ancuta P, Wang J, Gabuzda D. CD 16 monocytes produce IL-6,CCL2 and matrix metalloproteinase -9 upon interaction with CX3 CL1 - expressing endoteial cells. J Leukoc Biol 2006;80:1156-64.

13. Ji H, Li Y, Fan Z, Zuo B, Jian X, Li L, et al. Monocyte/lymphocyte ratio predicts the severity of coronary artery disease: a syntax score assessment. BMC Cardiovasc Disord 2017; 17:903.

14. Balta S, Celik T, Mikhailidis DP. The relation between atherosclerosis and the neutrophillymphocyte ratio. Clin Appl Thromb hemost 2016;22(5):405-411

15. Horne BD, Anderson JL, John JM, Weasver A, Bair TL, Jensen $\mathrm{Kr}$,et al. Which white blood cell subtypes predict increased cardiovascular risk? J Am coll cardiol 2005;45:1638-1643

16. Kadoya M, Koyama H, Kurajoh M,Kanzaki A, Kakutani Hatayama M,Okazaki H, et al. Sleep, cardiac autonomic function, and atherosclerosis in patients with cardiovascular risks: HSCAA study. Atherosclerosis 2015;238:409-414.

17. Tracey KJ. Reflex control of immunity. Nat Rev Immunuol 2009;9(6):418-428.

18. Bolayir A, Gokce SF. The role of mean platelet volume, platelet distrubition width and platelet/lymphocyte ration in development of cerebral venous thrombosis. Cumhuriyet Medical Journal 2017;39:683-691.

19. Urra $X$, Villamor N, Amaro S, et al. Monocyte subtypes predict clinical course and prognosis in human stroke. J Cereb Blood Flow Metab 2009;29:994-1002. 